\section{Diversity pattern of vegetation in and around proposed Kotlibhel hydroelectric project along the Alaknanda River in Garhwal Himalaya (India)}

\section{Singh V, Dasgupta S, Jhaldiyal V, Chauhan DS, Todaria NP}

The study made an assessment of the floral status of the project site of Kotlibhel hydrolectric project (Stage 1B) at Alaknanda valley in the Ganga river system (India). Study area included two broad zones: Influence (IZ) and Submergence zone (SZ). Influence zone showed higher species richness in all vegetation strata. In the upper layer, there were 26 tree species, middle layer consisted of 32 shrub species and ground layer (understory) contained 41 species. Maximum density in the tree layer (36.4 plants/ha) was found for Haldinia cordifolia in the Influence zone. On the other hand, shrub and herb species showed highest density in the Submergence zone. Highest density of shrubs species was recorded for Ficus hederacea (844.0 plants/ha), while highest density of herbs for Desmodium triflorum (5540.1 plants/ha). Significant differences in Shannon diversity were found between Influence and Submergence zones for shrub and herb species $(P<0.001)$, but not for trees. Simpson diversity was not significantly different for tree, shrub and herb species in both zones. Differences in Margalef species richness were found $(P<0.001)$ for all vegetation layers in both zones. Distribution pattern of the species showed contagious patterns for both Submergence and Influence zone. Maximum Shannon diversity (3.561) was recorded in the Influence zone for herb species, followed by shrubs species (3.184) and tree species (2.593). Submergence zone showed lower Shannon diversity than the Influence zone, where a higher Shannon diversity (3.480) was recorded for herb species. Pinus roxburghii showed the highest IVI in the Influence zone (71.88) and Mangifera indica in Submergence zone (58.77).

Keywords: Density, Diversity, Influence zone, Submergence zone diversity actually hampers and contrasts economic development (Kim \& Weaver 1994). The depletion of biodiversity is an alarming problem of the world. The rate of extinction has been enhanced by human-related habi-tat loss and climate change (Singh \& Kushwaha 2008). Land and water resources are limited and their wide utilization is increasing, especially for countries like India, where population pressure is continuously increasing (Vittala et al. 2008). The implications of these are remarkable, as will lose crucial life-supporting systems through the loss of important habitats, undermining rural livelihoods because of the degradation of natural resources on which people depend. It shall also diminish economic opportunities, as options for developing medicines and foods will reduce and the natural resource base for tourism will be damaged. Transfer of forest and agricultural lands to industries, hydroelectricity and thermal electricity projects, etc. are current investments. But what do we do to compensate the loss of the agriculture and forest? This is important in a context where the $70 \%$ of the country population lives in villages and depends on agriculture and forest for his livelihood. In addition, social and environmental aspects also need attention. Everybody knows why and to what extent forest resources are essential to protect life on earth. Therefore, documentation on current habitat structure and resource distribution and richness is necessary to estimate their loss. Biodiversity is also being depleted because of legal and illegal trade in econo-

\section{Introduction}

Forests are being degraded and fragmented rapidly in the Indian subcontinent. The human influences on biodiversity and ecosystem are rapid and large, leading to frequent changes in land and resource use, increased frequency of biotic invasions, reduction in species number, creation of stresses and the potential for changes in the climate system (Kumar \& Ram 2005). The loss of bio-

Department of Forestry, HNB Gharwal University Campus, Srinagar, Garhwal, Uttarakhand (India)

@ Vikaspal Singh (vikaspals@gmail.com) Received: Sep 10, 2010 - Accepted: Dec 13, 2010

Citation: Singh V, Dasgupta S, Jhaldiyal V, Chauhan DS, Todaria NP, 2011. Diversity pattern of vegetation in and around proposed Kotlibhel hydroelectric project along the Alaknanda River in Garhwal Himalaya (India). iForest 4: 38-43 [online: 2011-01-27] URL:

http://www.sisef.it/iforest/show.php? id $=557$

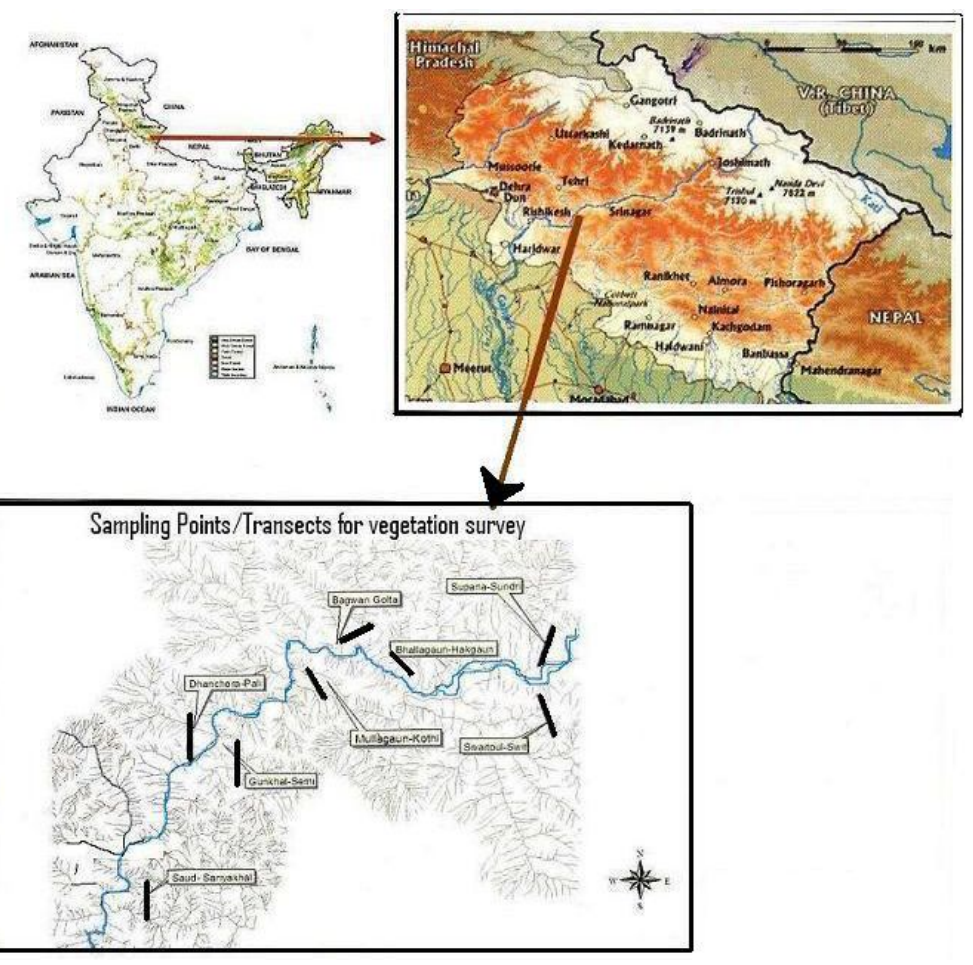

Fig. 1 - The study area. 
Tab. 1 - Vegetational characteristics of tree species in the Influence and Submergence zones of the study area. (NR): species present but not recorded within sampled quadrate; (Abs): absent. For the list of additional species found outside the sample plots, see Tab. SM1 in the Supplementary Materials.

\begin{tabular}{|c|c|c|c|c|c|c|c|c|c|c|}
\hline \multirow{2}{*}{ Species } & \multicolumn{5}{|c|}{ Influence zone } & \multicolumn{5}{|c|}{ Submergence zone } \\
\hline & Den & Abu & Fre & IVI & $\mathbf{A} / \mathbf{F}$ & Den & Abu & Fre & IVI & $\mathbf{A} / \mathbf{F}$ \\
\hline Acacia catechu & 7.3 & 1.83 & 12.5 & 9.25 & 0.15 & 22.5 & 2.33 & 18.8 & 29.31 & 0.1 \\
\hline Aegle marmalos & 9.3 & 2 & 14.6 & 10.05 & 0.14 & 13.9 & 2.62 & 27.1 & 14.24 & 0.12 \\
\hline Albizia lebbek & 4 & 2 & 6.3 & 3.53 & 0.32 & 2 & 1 & 6.3 & 3.71 & 0.16 \\
\hline Bauhinia variegata & 2.7 & 1.33 & 6.3 & 3.67 & 0.21 & & & Abs & & \\
\hline Bombex cieba & 4 & 1.5 & 8.3 & 9.65 & 0.18 & 9.3 & 2 & 14.6 & 10.64 & 0.14 \\
\hline Carica papaya & 1.3 & 1 & 4.2 & 1.63 & 0.24 & & & NR & & \\
\hline Cassia fistula & 2 & 1.5 & 4.2 & 2.61 & 0.36 & 6.6 & 3.33 & 6.3 & 6.46 & 0.53 \\
\hline Celtis australis & & & NR & & & 1.3 & 2 & 2.1 & 1.73 & 0.96 \\
\hline Dalbergia sissoo & 2 & 1 & 6.3 & 4.07 & 0.16 & 2 & 1.5 & 4.2 & 3.45 & 0.36 \\
\hline Delonix regia & 0.7 & 1 & 2.1 & 1.74 & 0.48 & & & Abs & & \\
\hline Eucalyptus camaldulensis & & & Abs & & & 4.6 & 7 & 2.1 & 11.14 & 3.36 \\
\hline Ficus religiosa & & & NR & & & 3.3 & 2.5 & 4.2 & 3.55 & 0.6 \\
\hline Grevillia robusta & & & NR & & & 2.7 & 4 & 2.1 & 3.76 & 1.92 \\
\hline Haldinia cordifolia & 36.4 & 1.2 & 95.8 & 46.99 & 0.01 & 8 & 4 & 6.3 & 8.73 & 0.64 \\
\hline Holoptelea integrifolia & 29.2 & 1.19 & 77.1 & 37.55 & 0.02 & 26.5 & 3.08 & 27.1 & 23.87 & 0.11 \\
\hline Juglans regia & 1.3 & 2 & 2.1 & 1.43 & 0.96 & & & Abs & & \\
\hline Lannea coromendelica & 3.3 & 1.25 & 8.3 & 7.06 & 0.15 & 33.8 & 3.4 & 31.3 & 31.71 & 0.11 \\
\hline Leucaena leucocephala & 4 & 2 & 6.3 & 4.38 & 0.32 & 9.3 & 2.8 & 10.4 & 8.68 & 0.27 \\
\hline Mallotus philippensis & 27.8 & 1.2 & 72.9 & 33.57 & 0.02 & 25.8 & 2.6 & 31.3 & 26.14 & 0.08 \\
\hline Mangifera indica & 6.6 & 2.5 & 8.3 & 23.6 & 0.3 & 12.6 & 2.71 & 14.6 & 58.77 & 0.19 \\
\hline Melia azedarach & 4 & 2 & 6.3 & 4.34 & 0.32 & 6 & 3 & 6.3 & 5.55 & 0.48 \\
\hline Morus alba & 4 & 3 & 4.2 & 4.29 & 0.72 & & & NR & & \\
\hline Musa paradisca & 2.7 & 2 & 4.2 & 2.29 & 0.48 & & & Abs & & \\
\hline Ougenia ooginansis & & & NR & & & 1.3 & 1 & 4.2 & 6.71 & 0.24 \\
\hline Phyllanthus emblica & 2 & 1.5 & 4.2 & 2.05 & 0.36 & & & Abs & & \\
\hline Pinus roxburghii & 33.1 & 1.16 & 89.6 & 71.88 & 0.01 & 32.5 & 3.5 & 29.2 & 38.96 & 0.12 \\
\hline Pyrus phasia & 1.3 & 1 & 4.2 & 1.64 & 0.24 & & & Abs & & \\
\hline Syzygium cumini & 4.6 & 2.33 & 6.3 & 4.52 & 0.37 & & & NR & & \\
\hline Tectona grandis & 1.3 & 1 & 4.2 & 2.24 & 0.24 & & & Abs & & \\
\hline Terminalia chebula & 1.3 & 2 & 2.1 & 2.11 & 0.96 & 1.3 & 2 & 2.1 & 2.91 & 0.96 \\
\hline Toona hexandra & 3.3 & 1.25 & 8.3 & 3.84 & 0.15 & & & NR & & \\
\hline Total & 199.4 & & & 300 & & 225.3 & & & 300 & \\
\hline
\end{tabular}

mically and medicinally important species (Singh \& Kushwaha 2008). Keeping in view the necessity of documentation on flora degradation before now, a study was conducted in the project area of Kotlibhel hydroelectric power project 1B (KHEP-1B) in Uttarakhand. The project is likely to submerge about 502.35 ha of land, classified as "Submergence zone". Some of the areas around the reservoir are also going to be disturbed due to different project related activity and was classified as "Influence zone" The present study deals with the diversity pattern and vegetation characters of the Influence and Submergence zone of the KHEP-1B.

\section{Methodology}

To analyze plant diversity, a study was conducted in the area of about $350 \mathrm{~km}^{2}$ along rivers Alaknanda and Ganga between Srina- gar and Devprayag. The area covers a stretch of about $30 \mathrm{~km}$ long and $7 \mathrm{~km}$ wide.

The vegetational analysis was conducted since June 2005 to Feb 2006. The study area was divided into two subareas: "Influence zone" (IZ) and "Submergence zone" (SZ) along the reservoir, as proposed by the Dam authority. The area subjected to submersion up to full reservoir level (FRL - approx. 325 $\mathrm{m}$ a.s.1.) was considered as submergence zone and the area along the reservoir up to 7 $\mathrm{km}$ radius around the reservoir was considered as influence zone. Some 8 transects were analyzed in the entire study area: SupanaSundari, Switpul-Swit, Bhallagaun-Hakgaun, Bagwan-Golta, Mullagaun-Kothi, GunkhalSemi, Dhanchera-Pali and Saud- Sariyakhal. Each transect was $1500 \mathrm{~m}$ long, from the river water level along an increasing altitudinal gradient (Fig. 1). Transects were spa- tially distributed so as to minimize the autocorrelation among the vegetation. Along each transect, six circular plots (each of $10 \mathrm{~m}$ radius) at $200 \mathrm{~m}$ intervals were sampled. Circular plots were used for sampling due to undulating surface of the study area. Trees in circular plots were enumerated.

Within each $10 \mathrm{~m}$ radius plot, a nested circular plot of $5 \mathrm{~m}$ radius was sampled for recording shrubs, whereas four nested circular plots of $1 \mathrm{~m}$ radius were established for herbs analisys. Herbs were recorded by point-intercept method for their proportional representation in the area. In order to prepare a checklist and best represent the species from the area, an intensive search was made by re-tracing belt transects in three different seasons.

Species characterized by short stature, including annual or biennial herbs, and by 
Tab. 2 - Vegetational characteristics of shrub species in the Influence and Submergence zones of the study area. (NR): species present but not recorded within sampled quadrate; (Abs): absent. For the list of additional species found outside the sample plots, see Tab. SM2 in the Supplementary Materials.

\begin{tabular}{|c|c|c|c|c|c|c|c|c|c|c|}
\hline \multirow{2}{*}{ Species } & \multicolumn{5}{|c|}{ Influence zone } & \multicolumn{5}{|c|}{ Submergence zone } \\
\hline & Den & Abu & Fre & IVI & $\mathbf{A} / \mathbf{F}$ & Den & Abu & Fre & IVI & $\mathbf{A} / \mathbf{F}$ \\
\hline Adathoda zeylanica & 299.9 & 2.8 & 83.3 & 9.3 & 0.03 & 146 & 1.49 & 77.1 & 15.12 & 0.02 \\
\hline Aerva sanquinolenta & 66.4 & 1.5 & 35.4 & 3.1 & 0.04 & 53.1 & 3.33 & 12.5 & 3.23 & 0.27 \\
\hline Agave fastigata & 108.8 & 2.4 & 35.4 & 3.7 & 0.07 & 45.1 & 3.4 & 10.4 & 2.72 & 0.33 \\
\hline Artemisia roxburghiana & 400.8 & 3.4 & 93.8 & 11.4 & 0.04 & 47.8 & 3.6 & 10.4 & 2.79 & 0.35 \\
\hline Asparagus adscendens & 100.9 & 5.4 & 14.6 & 2.3 & 0.37 & & & NR & & \\
\hline Bambusa arundinaceae & 74.3 & 3.5 & 16.7 & 2.1 & 0.21 & 106.2 & 3.33 & 25 & 6.46 & 0.13 \\
\hline Barleria cristata & 467.1 & 3.7 & 100 & 12.7 & 0.04 & 42.5 & 2 & 16.7 & 3.56 & 0.12 \\
\hline Cajanus mollis & 98.2 & 3.4 & 22.9 & 2.8 & 0.15 & 61 & 2.09 & 22.9 & 4.96 & 0.09 \\
\hline Cannavis sativa & 456.5 & 4 & 89.6 & 11.9 & 0.05 & & & NR & & \\
\hline Carrisa opeca & 355.7 & 2.8 & 100 & 11.1 & 0.03 & 506.9 & 4.66 & 85.4 & 25.9 & 0.06 \\
\hline Cassia tora & 169.9 & 1.8 & 72.9 & 6.8 & 0.03 & 124.7 & 3.13 & 31.3 & 7.87 & 0.1 \\
\hline Colebrookia oppositifolia & 164.6 & 4.1 & 31.3 & 4.2 & 0.13 & 39.8 & 2.14 & 14.6 & 3.18 & 0.15 \\
\hline Cotinus coggygria & 55.7 & 4.2 & 10.4 & 1.4 & 0.4 & 90.2 & 4.25 & 16.7 & 4.82 & 0.26 \\
\hline Debregeasia longifolia & 47.8 & 3 & 12.5 & 1.4 & 0.24 & 18.6 & 2.33 & 6.3 & 1.4 & 0.37 \\
\hline Eupatorium adenophorum & 292 & 2.8 & 83.3 & 9.2 & 0.03 & 8 & 1.5 & 4.2 & 0.82 & 0.36 \\
\hline Euphorbia royleana & 63.7 & 2.7 & 18.8 & 2 & 0.14 & 18.6 & 2.33 & 6.3 & 1.4 & 0.37 \\
\hline Ficus hederacea & 103.5 & 2.6 & 31.3 & 3.4 & 0.08 & 844 & 7.57 & 89.6 & 35.14 & 0.09 \\
\hline Lantana camara & 453.9 & 3.6 & 100 & 12.5 & 0.04 & 499 & 4.7 & 83.3 & 25.39 & 0.06 \\
\hline Murrya koenigii & 589.2 & 4.6 & 100 & 14.5 & 0.05 & 29.2 & 2.2 & 10.4 & 2.29 & 0.21 \\
\hline Nyctanthes arbo-tritis & 84.9 & 3.6 & 18.8 & 2.3 & 0.19 & 100.9 & 4.75 & 16.7 & 5.11 & 0.29 \\
\hline Pueraria tuberosa & 63.7 & 4 & 12.5 & 1.7 & 0.32 & 809.5 & 7.09 & 87.5 & 34.53 & 0.08 \\
\hline Pupalia lapaca & 61 & 1.9 & 25 & 2.4 & 0.08 & & & NR & & \\
\hline Reinwardtia indica & 90.2 & 1.7 & 41.7 & 3.8 & 0.04 & & & NR & & \\
\hline Rhus parviflora & 445.9 & 3.7 & 93.8 & 12 & 0.04 & 8 & 1.5 & 4.2 & 0.82 & 0.36 \\
\hline Ricinus communsis & 483.1 & 3.8 & 100 & 12.9 & 0.04 & & & NR & & \\
\hline Rubus ellipticus & 464.5 & 3.8 & 95.8 & 12.4 & 0.04 & & & Abs & & \\
\hline Sida cordifolia & 98.2 & 1.4 & 54.2 & 4.7 & 0.03 & & & NR & & \\
\hline Tephrosia candida & 236.2 & 3.7 & 50 & 6.4 & 0.07 & 50.4 & 4.75 & 8.3 & 2.55 & 0.57 \\
\hline Urtica dioica & 50.4 & 2.4 & 16.7 & 1.7 & 0.14 & 10.6 & 2 & 4.2 & 0.89 & 0.48 \\
\hline Woodfordia fruiticosa & 172.5 & 2.6 & 52.1 & 5.6 & 0.05 & 21.2 & 2 & 8.3 & 1.78 & 0.24 \\
\hline Xanthium indicum & 90.2 & 3.4 & 20.8 & 2.5 & 0.16 & & & NR & & \\
\hline Ziziphus oxyphylla & 252.1 & 5.6 & 35.4 & 5.7 & 0.16 & 90.2 & 2.13 & 33.3 & 7.26 & 0.06 \\
\hline Total & 6961.9 & & & 200 & & 3771.6 & & & 200 & \\
\hline
\end{tabular}

spiny structures (thorns and spines) were classified as shrubs. Herbs included shadeloving, annual, biennial or perennial, herbaceous species. Trees with cbh (circumference at breast height, i.e., $1.37 \mathrm{~m}$ above the ground) $>31.5 \mathrm{~cm}$ were individually counted in the $10 \mathrm{~m}$ radius plot. Herbarium sheets of species which could not be identified in the field were prepared, and identified later at the Department of Botany, HNB Garhwal University. Taxa names were assigned after the nomenclature proposed by Benthum \& Hooker (1883).

Frequency, density, abundance and their relative values for each species were obtained using the equations reported below (Misra 1968). The Important Value Index (IVI) for different species was calculated as sum of relative frequency (RF), relative density (RD) and relative abundance (A) of each species as follows (eqn. 1):

$$
I V I=R F+R D+A
$$

AF ratio for different species was determined for eliciting the distribution pattern in terms of regular $(\mathrm{AF}<0.025)$, random $(\mathrm{AF}=0.025-0.05)$ and contagious $(\mathrm{AF}>0.05)$, as follows (Curtis \& Cottam 1956 - eqn. 2):

$$
A F=\frac{\text { Abundance }}{\text { Frequency }}
$$

The Shannon's (1963) $H^{\prime}$ and Simpson's (1949) $D$ diversity indices were independently obtained as follows (eqn. 3, eqn. 4):

$$
\begin{gathered}
H^{\prime}=-\sum_{n} p_{i} \ln p_{i} \\
D=\sum_{i=1}^{n} p_{1}{ }^{2}
\end{gathered}
$$

where $p_{\text {i }}$ represents the proportional abundance of $i$-th species in any given transect. Species richness (SR) was calculated following Margalef (1958):

$$
S R=\frac{(S-1)}{\ln (N)}
$$

where $S$ is the number of species and $N$ the total number of individuals of all species.

\section{Results}

Vegetation analysis

In tree layer of IZ, maximum density (36.4 plants/ha) and frequency (95.8\%) was observed for Haldinia cordifolia followed by Pinus roxburghii (density: 33.1 plants/ha; frequency: $89.6 \%$ ) and Holoptelea integrifolia (density: 29.2 plants/ha; frequency: 
Tab. 3 - Vegetational characteristics of herb species in the Influence and Submergence zones of the study area. (NR): species present but not recorded within sampled quadrate; (Abs): absent. For the list of additional species found outside the sample plots, see Tab. SM3 in the Supplementary Materials.

\begin{tabular}{|c|c|c|c|c|c|c|c|c|c|c|}
\hline \multirow{2}{*}{ Species } & \multicolumn{5}{|c|}{ Influence zone } & \multicolumn{5}{|c|}{ Submergence zone } \\
\hline & Den & Abu & Fre & IVI & $\mathbf{A} / \mathbf{F}$ & Den & Abu & Fre & IVI & $\mathbf{A} / \mathbf{F}$ \\
\hline Ajuga bracteosa & 1791.4 & 0.97 & 44.3 & 6.3 & 0.03 & 1161.1 & 2.05 & 19.8 & 2.97 & 0.09 \\
\hline Alysicarpus bupleurifolius & 2023.6 & 1.07 & 43.2 & 6.58 & 0.03 & 2023.6 & 1.83 & 29.7 & 4.82 & 0.07 \\
\hline Anaphalis adnata & 1227.4 & 1.73 & 29.7 & 4.27 & 0.04 & \multicolumn{5}{|c|}{ Abs } \\
\hline Artimissia capalaris & 879.1 & 2.43 & 14.1 & 2.49 & 0.14 & 1857.7 & 1.3 & 29.7 & 4.6 & 0.07 \\
\hline Arundinella nepalensis & 1061.6 & 1.54 & 15.1 & 2.86 & 0.15 & \multicolumn{5}{|c|}{ NR } \\
\hline Bidens pilosa & 1940.7 & 2 & 42.7 & 6.41 & 0.03 & \multicolumn{5}{|c|}{ Abs } \\
\hline Brachiaria ramosa & 597.1 & 1.96 & 8.9 & 1.63 & 0.24 & 1459.7 & 2 & 16.7 & 3.12 & 0.17 \\
\hline Cassia absus & 1210.8 & 1.51 & 15.6 & 3.13 & 0.16 & 3715.5 & 1.43 & 58.3 & 9.13 & 0.03 \\
\hline Celosia argentea & 1327 & 1.79 & 27.6 & 4.26 & 0.06 & 2537.8 & 1.37 & 37.5 & 6.06 & 0.06 \\
\hline Chrysopogon aciculatus & 5506.9 & 1.45 & 100 & 16.52 & 0.02 & 1310.4 & 1.96 & 30.2 & 3.94 & 0.05 \\
\hline Chrysopogon fulvus & 2040.2 & 1.66 & 51 & 7.22 & 0.03 & 1808 & 2.13 & 31.3 & 4.66 & 0.06 \\
\hline Crotolaria medicagina & 663.5 & 1.47 & 13.5 & 2.11 & 0.11 & 1426.5 & 1.48 & 31.3 & 4.17 & 0.05 \\
\hline Cynadon dactylon & 3781.8 & 1.76 & 100 & 13.81 & 0.01 & 4362.4 & 1.22 & 43.2 & 8.83 & 0.07 \\
\hline Cynoglosum glochidiatum & 2703.7 & 2.75 & 49 & 8.1 & 0.04 & 928.9 & 1.45 & 22.4 & 2.87 & 0.06 \\
\hline Cyperus comprsssus & 829.3 & 2.16 & 12 & 2.25 & 0.18 & 2040.2 & 2.14 & 42.7 & 5.81 & 0.04 \\
\hline Datura innoxia & 1409.9 & 1.56 & 18.8 & 3.69 & 0.13 & 1973.9 & 2.87 & 24 & 4.32 & 0.11 \\
\hline Desmodium triflorum & 3018.8 & 2.04 & 97.4 & 12.41 & 0.01 & 5540.1 & 2.08 & 84.9 & 13.45 & 0.02 \\
\hline Digitaria ciliaris & 1575.8 & 1.43 & 19.8 & 4.03 & 0.13 & 1625.5 & 2.07 & 13.5 & 3.1 & 0.28 \\
\hline Eragrostis minor & 1310.4 & 1.43 & 14.1 & 3.16 & 0.21 & 1443.1 & 1.32 & 24.5 & 3.68 & 0.08 \\
\hline Euphorbia hirta & 1244 & 1.43 & 25 & 3.92 & 0.06 & 1360.1 & 1.94 & 32.3 & 4.16 & 0.04 \\
\hline Evolvulus alsinoides & 3416.9 & 1.8 & 100 & 13.24 & 0.01 & 1758.2 & 1.84 & 30.2 & 4.51 & 0.06 \\
\hline Fumaria indica & 879.1 & 1.76 & 13.5 & 2.45 & 0.15 & 1111.3 & 1.82 & 21.4 & 3.02 & 0.08 \\
\hline Galium aprine & 978.6 & 2.36 & 14.6 & 2.69 & 0.14 & 1824.6 & 1.67 & 46.9 & 5.85 & 0.03 \\
\hline Geranium ocelatum & 564 & 1.46 & 9.9 & 1.66 & 0.18 & 2007 & 2.59 & 42.7 & 5.77 & 0.04 \\
\hline Heteropogon controtus & 1459.7 & 1.3 & 18.2 & 3.73 & 0.14 & 5457.1 & 2.05 & 89.6 & 13.7 & 0.02 \\
\hline Heteropogon melanocarpus & \multicolumn{5}{|c|}{ NR } & 5490.3 & 2.09 & 96.4 & 14.25 & 0.02 \\
\hline Ipomoea hederifolia & 514.2 & 2.23 & 9.9 & 1.59 & 0.17 & 1575.8 & 1.42 & 27.6 & 4.09 & 0.07 \\
\hline Leucas cephalotes & 547.4 & 1.68 & 6.3 & 1.35 & 0.44 & 1277.2 & 1.82 & 19.3 & 3.08 & 0.11 \\
\hline Leucas lanata & 1210.8 & 1.27 & 22.9 & 3.71 & 0.07 & 2471.5 & 1.85 & 53.6 & 7.18 & 0.03 \\
\hline Malva sylvestris & 1327 & 1.73 & 19.3 & 3.6 & 0.11 & 1509.4 & 1.36 & 22.9 & 3.65 & 0.09 \\
\hline Micromaria biflora & 2189.5 & 2.93 & 39.1 & 6.51 & 0.05 & 1426.5 & 1.91 & 15.6 & 3 & 0.18 \\
\hline Nepeta hindostana & 1443.1 & 1.26 & 20.3 & 3.87 & 0.11 & 1210.8 & 1.79 & 18.2 & 2.92 & 0.11 \\
\hline Nicotiana plumbaginifolia & 1161.1 & 2.51 & 25 & 3.79 & 0.06 & 1327 & 3.17 & 20.3 & 3.22 & 0.1 \\
\hline Origanum vulgare & 1725 & 1.19 & 30.7 & 5.13 & 0.06 & \multicolumn{5}{|c|}{ Abs } \\
\hline Oxalis corniculata & 912.3 & 2.17 & 14.1 & 2.54 & 0.15 & 1608.9 & 1.5 & 26 & 4.01 & 0.07 \\
\hline Physalis divaricata & 1177.7 & 2.21 & 25.5 & 3.86 & 0.06 & 2703.7 & 2.75 & 69.8 & 8.69 & 0.02 \\
\hline Rumx hastatus & 1874.3 & 2.12 & 41.1 & 6.18 & 0.04 & 1874.3 & 3.77 & 32.3 & 4.82 & 0.06 \\
\hline Scutellaria scandems & 1310.4 & 2.5 & 24.5 & 3.99 & 0.07 & 1741.6 & 1.22 & 38.5 & 5.12 & 0.04 \\
\hline Sedum multicaule & 1127.9 & 2.11 & 17.7 & 3.17 & 0.11 & 2156.3 & 1.79 & 49.5 & 6.47 & 0.03 \\
\hline Sida rhombifolia & 1111.3 & 1.63 & 22.9 & 3.55 & 0.07 & 1575.8 & 1.63 & 18.8 & 3.42 & 0.14 \\
\hline Sida cordata & 1327 & 2.04 & 29.2 & 4.38 & 0.05 & \multicolumn{5}{|c|}{ NR } \\
\hline Viola canescens & 1310.4 & 1.52 & 22.9 & 3.86 & 0.08 & 1327 & 2.64 & 25 & 3.57 & 0.07 \\
\hline Total & 63710.6 & \multicolumn{4}{|c|}{200} & 78008.6 & \multicolumn{4}{|c|}{200} \\
\hline
\end{tabular}

$77.1 \%)$. The IVI of different species ranged between 1.43 to 71.88 in IZ. Within SZ highest density (33.8 plants/ha) was recorded for Lannea coromendelica and lowest density (1.3 plants/ha) was recorded for Celtis australis, Ougenia ooginansis and Terminalia chebula. In this zone maximum fre- quency $(31.3 \%)$ was also found for Lannea coromendelica followed by Pinus roxburghii (29.2 \%) and Holoptelea integrifolia (27.1). The IVI values of different species within SZ were between 1.73 to 58.77 (Tab. 1).

In the IZ shrub layer, Murrya koenigii was the dominant species with maximum fre- quency $(100 \%)$, density (589.2 plants/ha) and IVI (14.5), while in the SZ Ficus hederacea was the dominant shrub with highest frequency $(89.6 \%)$, density (844.0 plants/ ha) and IVI (35.14). Minimum density (8.0 plants/ha) was observed for Eupatorium adenophorum and Rhus parviflora. Lowest fre- 
Tab. 4 - Diversity indices and species richness in the both zone of study area. IZ: Influence Zone; SZ: Submergence Zone.

\begin{tabular}{lcccccc}
\hline \multirow{2}{*}{\multicolumn{1}{c}{ Diversity indices }} & \multicolumn{2}{c}{ Tree } & \multicolumn{2}{c}{ Shrub } & \multicolumn{2}{c}{ Herb } \\
\cline { 2 - 7 } & $\mathbf{I Z}$ & $\mathbf{S Z}$ & $\mathbf{I Z}$ & $\mathbf{S Z}$ & $\mathbf{I Z}$ & \multicolumn{1}{c}{ SZ } \\
\hline Species Richness & 26 & 20 & 32 & 24 & 41 & 37 \\
Shannon index (H) & 2.430 & 2.643 & 3.184 & 2.37 & 3.561 & 3.48 \\
Simpson index (CD) & 0.134 & 0.086 & 0.050 & 0.138 & 0.034 & 0.036 \\
Margalef index (SR) & 4.6 & 4.0 & 3.9 & 3.2 & 4.8 & 4.3 \\
\hline
\end{tabular}

quency $(4.2 \%)$ was also observed for Eupatorium adenophorum, Rhus parviflora and Urtica dioica (Tab. 2).

In the IZ herb layer, Chrysopogon aciculatus showed highest density (5506.9 plants/ha) followed by Cynadon dactylon (3781.8 plants/ha) and Evolvulus alsinoides (3416.9 plants/ha). These species have also maximum frequency (100\%) among all herb species. The observed IVI for herb species was between 1.59 to 16.52 in this zone. On the other hand, in the SZ highest density (5540.1 plants/ha) was calculated for Desmodium triflorum followed by Heteropogon melanocarpus (5490.3 plants/ha) and Heteropogon controtus (5457.1 plants/ha), whereas maximum frequency $(96.4 \%)$ was recorded for Heteropogon melanocarpus and lowest frequency (13.5\%) for Digitaria ciliaris. The observed IVI value in this zone ranged between 2.87 to 14.25 (Tab. 3).

\section{Distribution pattern}

The abundance/frequency ratios (A/F) obtained showed that most of species were contagiously distributed in both IZ and SZ. In the tree layer, $84.5 \%$ species were found in contagious pattern within IZ and $15.4 \%$ were randomly distributed. For shrubs in the IZ, $50 \%$ species were in contagious and $50 \%$ in random distribution, while in SZ 95.8\% species were in contagious distribution and 4.2 $\%$ were in regular distribution pattern (Tab. 1, Tab. 2, Tab. 3).

\section{Diversity}

Among all vegetation layer of IZ and SZ, the maximum number of species was encountered for the herb layer of IZ (41) and the minimum (20) for the tree layer in the SZ. Shannon diversity $\left(H^{\prime}\right)$ was highest for the herb layer of IZ (3.561) and minimum for shrub layer of the SZ (2.370). The Simpson diversity was ranging between 0.034 to 0.138 . Margalef index showed maximum value for the herb layer in the IZ (4.8) and minimum (3.2) for shrub layer in the SZ (Tab. 4).

Shannon and Simpson diversity indices for tree layer did not show significant differences between IZ and SZ after $t$-test. On the other hand, Margalef index for trees showed significant difference between these two zones $(\mathrm{P}<0.001$, df. 13). Shannon diversity and Margalef indices for shrubs were signifi- cantly different bewteen IZ and SZ $(\mathrm{P}<0.001$, df 12$)$, while no significant differences were detected for Simpson diversity index. Herbs also showed the similar trend as shrubs of IZ and SZ.

\section{Discussion}

Disturbance has become a widespread feature in most of the forest all over the Himalaya (Singh \& Singh 1992). Knowledge on ecological process and biotic pressure may help in understanding the persistence of long-lived plant communities. Tree density observed in this study is lower than that recorded for mid-elevational forests in Central Himalaya (Khera et al. 2001), but similar to those reported (5 to 325 plants/ha) by Sanjeev et al. (2006) in a micro watershed area of Mussoorie in Garhwal Himalaya. Similarly, shrub densities in this study are lower than those reported by Hussain et al. (2008) but similar to what observed by Khera et al. (2001). Furthermore, Negi et al. (2008) reported herb density in Garhwal Himalaya similar to that found in the present study.

The changes in the dispersion patterns may reflect the reactions of species to disturbance, as well as to changes in the habitat conditions (Sagar et al. 2003). The analysis of species' distribution pattern based on the $\mathrm{A} / \mathrm{F}$ ratio indicated that most of the species of both zones were distributed in contagious pattern. Joshi \& Tiwari (1990) and Bhandari et al. (1998) also reported a fairly similar distribution pattern of woody vegetation in different parts of Garhwal Himalaya.

Shannon species diversity $\left(H^{\prime}\right)$ and concentration of dominance (cd) of the present study sites are more or less similar to the values reported by Kunwar \& Sharma (2004) in a comparative study between two community forests in Dolpa district of mid-west Nepal. These values were comparable with those reported for the Chir pine forest in Garhwal Himalaya (Bhandari et al. 1998). The low diversity oberved in this investigation may be interpreted as due to greater anthropogenic pressure.

Species richness in out study showed higher values for ground vegetation (herbs), followed by shrubs and trees. Khera et al. (2001) also found the same pattern of species richness. Hussain et al. (2008) also found overall 63 tree, 56 shrub, 90 herb and 21 grass species in Kumaon Himalaya. In a comparative study between Panchayat and Reserve forest in Garhwal Himalaya, Negi et al. (2008) reported a similar richness trend (Herb $>$ Tree $>$ Shrub). Saxena \& Singh (1982) have also recorded high species richness $(4$ to 22$)$ and diversity ( 0.74 to 3.10$)$ for shrub layer in Kumaun Himalaya. Influence zone showed a higher species richness in our study, while Adhikari et al. (2009) found higher richness in the Submergence zone of the Tehri hydroelectric dam in Uttarakhand.

\section{Conclusion}

The vegetation of the study area is important for sustaining the livelihood of local people. The present study suggests that the influence zone has the maximum species diversity and richness. Diversity was high where the dominance of canopy species was major and low near agricultural fields or on disturbed sites. The vegetation composition of both zones was found almost in similar pattern, though species richness was larger in the Influence zone. Hence, it may be hypothesized that after construction of proposed hydropower project there may be negligible effect on the species richness of the surrounding vegetation, but definitely a significant portion of the vegetation is going to be lost for ever. The change in landuse of riverine belt might also change the micro habitat requirement of many species. This of course require detailed investigation in order to conclude species specific impact of the proposed hydropower project.

\section{References}

Adhikari BS, Uniyal SK, Rawat GS (2009). Vegetation structure and community patterns of Tehri Dam Submergence Zone, Uttarakhand, India. EurAsian Journal of Biosciences. 3: 40-49.

Bentham G, Hooker JD (1883). Genera Plantarum (3 vols). London, UK.

Bhandari BS, Mehta JP, Tiwari SC (1998). Woody vegetation structure along an altitudinal gradient in a part of Garhwal Himalaya. Journal of Hill Research 11 (1): 26-31.

Curtis JT, Cottam G (1956). Plant ecology workbook. Laboratory field reference manual. Burgers Publication Co., MN, USA, pp. 193.

Hussain MS, Sulatana A, Khan JA, Khan A (2008). Species composition and community structure of forest stands in Kumaon Himalaya, Uttarakhand, India. Tropical Ecology 49 (2):167181. [online] URL: http://www.tropecol.com/ pdf/open/PDF_49_2/08\%20Hussain.pdf

Joshi NK, Tiwari SC (1990). Phytosociological analysis of woody vegetation along an altitudinal gradient in Garhwal Himalya. Indian Journal of Forestry 13 (4): 322-328. [online] URL: http://www.cabdirect.org/abstracts/19930672835. html

Khera N, Kumar A, Ram J, Tewari A (2001). Plant biodiversity assessment in relation to disturbances in mid elevation forest of Central Himalaya, India. International Society for Tropical 
Ecology 42 (1): 83-95. [online] URL: http://tropecol.com/pdf/open/PDF_42_1/42109.pdf

Kim KC, Weaver RD (1994). Biodiversity and landscapes. Cambridge University Press, New York, USA, pp. 3-27.

Kumar A, Ram J (2005). Anthropogenic disturbances and plant biodiversity in forest of Uttaranchal, Central Himalaya. Biodiversity and Conservation 14: 309-311. - doi: 10.1007/ s10531-004-5047-4

Kunwar RM, Sharma SP (2004). Quantitative analysis of tree species in two community forests of Dolpa district, mid-west Nepal. Himalayan Journal of Sciences 2 (3): 23-28.

Misra R (1968). Ecology work book. Oxford and IBH publishing Co. New Delhi, India, pp. 244.

Margalef R (1958). Information theory in ecology. General Systems 3: 36-71.

Negi BS, Chauhan DS, Todaria NP (2008). Com- parative plant diversity between panchayat and adjoining reserve forests in Garhwal Himalaya. Indian Journal of Forestry 31(4): 585-593. - doi: 10.1007/s10531-004-5047-4

Sagar R, Rahgubanshi AS, Singh JS (2003). Comparison of community composition and species diversity of understory and overstory tree species in a dry tropical forest of northern India. Journal of Environment Management 88: 1037-1046. doi: 10.1016/j.jenvman.2007.05.013

Sanjeev B, Gera M, Sankhayan PL (2006). Phytosociological analysis of Arnigad micro watershed in Mussoorie hills of Garhwal Himalaya. Indian Forester 132 (1): 19-30.

Saxena AK, Singh JS (1982). A phytosociological analysis of woody species in forest in forest communities of a part of Kumaon Himalaya. Vegetatio 50: 2-3.

Shannon CE,Wiener W (1963). The mathematical theory of communication. University of Illinois Press, Urbana, IL, USA, pp. 117.

Simpson EM (1949). Measurement of diversity. Nature 163: 688. - doi: 10.1038/163688a0

Singh JS, Kushwaha SPS (2008). Forest biodiversity and conservation in India. International Forestry Review 10 (2): 292-304. - doi: 10.1505/ ifor.10.2.292

Singh JS, Singh SP (1992). Forests of Himalaya: structure, functioning and Impact of management. Gyanodaya Prakashan, Nainital, India.

Vittala SS, Govindaiah S, Honne Gowda H (2008). Prioritization of sub-watersheds for sustainable development and management of natural resources: An integrated approach using remote sensing, GIS and socio-economic data. Current Science 95 (3): 345-354. [online] URL: http://www.ias.ac.in/currsci/aug102008/345.pdf 